\title{
Dialogue
}

Crime and Criminality: Historical Differences in Hawai ${ }^{i} i$

SALLY ENGLE MERRY

The Contemporary Pacific, Volume 14, Number 2, Fall 2002, 411-424

(C) 2002 by University of Hawai 'i Press 


\section{Crime and Criminality: \\ Historical Differences in Hawai'i}

Sally Engle Merry

$\mathrm{N}$ ative Hawaiians are disproportionately arrested and incarcerated in
the state of Hawai'i, according to statistics from the criminal justice system. Asians are underrepresented and whites are represented slightly above their proportion of the population. Although these statistics have sometimes been used to make arguments about criminal propensities, I argue that such differences are not inherent but are socially produced. They reflect the kinds of behavior that are defined as criminal and subjected to energetic arrest, prosecution, and conviction, while other behaviors are ignored. This process of criminalization reflects political concerns about specific crimes as well as about particular groups. Using historical data, I argue that criminalization is a social process that zeroes in on certain populations and their activities. Its targets change over time with alterations in historical circumstances. Of course, it is important to recognize that ethnic identity is not unambiguous in Hawai'i. Many people have multiple ancestries and chose among them for purposes of statistical recording.

According to the 2000 census, which allowed respondents to select single or multiple racial categories, just 6.6 percent of the state's population listed Native Hawaiian as their only race, and 23.3 percent listed "Native Hawaiian or other Pacific Islander" as one of multiple racial designations (see table I). ${ }^{1}$ Yet in I999, 36 percent of juveniles arrested for serious crimes (so-called index offenses) and 38 percent of those arrested for less serious crimes were Hawaiians. Among adults, Hawaiians accounted for 2I percent of those arrested for serious crimes and 24 percent of arrests for less serious crimes (see table 2). ${ }^{2}$

Looking at single racial categories and adult arrest rates, the white population also appears to be overrepresented: In 1999, whites accounted for 36 percent of adults arrested for serious crimes and 35 percent for less serious crimes, while according to the census, just 24.3 percent defined themselves as white only. However, 39 percent of census respondents chose 
white as one of multiple racial categories; and white juveniles arrested for less serious or serious crimes, respectively, accounted for only 2 I-22 percent of the total juvenile arrests in I999. The data for Asians offers the most striking contrast: 58.0 percent of Hawai' $i$ residents in the 2000 census named "Asian" as one of their races, and 4I.6 percent listed it as their only race. But Asians (Chinese, Japanese, Filipino, and Korean) accounted for only 25 percent of adults arrested for serious crimes, 23 percent for less serious crimes, and 25-26 percent of juvenile arrests. Even with the difficulties of classifying racial or ethnic identity, it appears that Hawaiians are

Table I. Ethnicity Reported in Census of Hawai'i, 2000 (Percent)

\begin{tabular}{lcc}
\hline & Single Ethnicity & Multiple Ethnicities \\
\hline Native Hawaiian & 6.6 & $23.3^{*}$ \\
White & 24.3 & 39.3 \\
Asian & 41.6 & 58.0 \\
\hline
\end{tabular}

Source: United States Census 2000, Table DP-I.

* Native Hawaiian and Other Pacific Islander combined.

Table 2. Arrests in Hawai'i by Ethnicity, 1999 (Percent)

\begin{tabular}{lccc}
\hline & Hawaiians & Whites & Asians* \\
\hline Adults & & & \\
$\quad$ Serious Crimes & 21 & 36 & 25 \\
$\quad$ Less Serious Crimes & 24 & 35 & 23 \\
Juveniles & & & \\
$\quad$ Serious Crimes & 36 & 22 & 26 \\
$\quad$ Less Serious Crimes & 38 & 21 & 25 \\
\hline
\end{tabular}

Source: Richard, Allen, and Perrone 2000, I09, I I I, II 3 , I I 5.

* Chinese, Japanese, Filipino, and Korean. 
arrested disproportionately more often thanAsians in Hawai' $i$, with whites somewhere in between.

This pattern seems particularly marked for juveniles and for lifestyle offenses such as drug consumption. For example, in 1996, 22.2 percent of all adults and 37.9 percent of all juveniles arrested for drug offenses were Native Hawaiians (Richmond and Perrone 1997). Other statistics echo this pattern: From I983 to I988, 28.8 percent of inmates in one jail in Hawai'i were Native Hawaiians (Attorney General 1993). During the I990s, Hawaiians represented about 20 percent of the population of East Hawai'i but amounted to 39 percent of the men and women involved in a feminist batterer intervention program in that area. Of the population seeking protective orders for violence in the family in Family Court in the early I990s, 27 percent were Hawaiians (see Merry I995; 200I).

At first glance, it seems that Native Hawaiians are simply more criminally inclined than other ethnic groups in the state. However, this apparently obvious conclusion is critically flawed. It fails to consider all the factors that enter into the number of arrests, convictions, and imprisonments for any group. It is essential to take a historical perspective and consider the larger social context within which certain behaviors are defined as crimes and viewed as serious enough to warrant arrest, prosecution, and punishment. This context is deeply influenced by economic needs for land and labor, and by social reformist agendas focused on the nature of marriage and the family. Arrest rates reflect these social contexts, as demonstrated by an analysis of the shifting caseloads of the Hilo District Court in Hawai'i during the nineteenth century.

There are three principal factors in differential arrest and incarceration rates. First, within any social system some actions are specified as crimes and others are not, and societies differ in the kinds of activities they label crimes. The process of defining certain behaviors as criminal is both social and historical. For example, colonial rule typically introduces a legal system that criminalizes a range of behaviors previously not considered crimes by the colonized. These newly created crimes are often lifestyle offenses, such as drinking alcohol or holding certain festivals, or economically based crimes, such as failure to work according to the terms of a contract.

Second, in any society, only some of the crimes delineated in the governing legal code win particular attention from the general public and the police. Only these evoke regular efforts to report and arrest those who engage in this behavior, while many other crimes on the books are simply tolerated or ignored. Sometimes a crime that was formerly the focus of 
considerable public concern and outrage disappears from public view although it remains a legal offense. Fornication is a good example; during the nineteenth century it was a major concern in much of the United States, but though it remains a crime in some states, it is rarely prosecuted now.

Third, prosecutors, defense attorneys, and judges differ in how serious they consider certain offenses, and the likelihood of conviction and incarceration for a particular behavior varies accordingly. Judicial concern shifts over time, particularly in the domain of lifestyle activities such as drug consumption and cock fighting. Offenses that were minimized at one time, such as wife battery, later emerge as major social problems as a result of political activism. New land and labor relationships create new offenses, such as violations of contract labor agreements. Thus, economic conditions and social reform agendas influence what kinds of behavior are given priority in the courts and what kinds are ignored. Finally, arrest and court decisions are also influenced by current ideas about what kinds of people are dangerous and need to be controlled.

The rate of incarceration of any group is a product of these three factors. It is not that any group is "naturally" criminal, but that groups differ in the extent to which their society defines their everyday practices as criminal and seriously pursues and prosecutes those behaviors. An examination of the caseloads of the Hilo Police Court in nineteenth century Hawai'i provides dramatic evidence of the way the introduction of a new legal system creates new criminality and how shifting public and judicial concerns change the populations that are in court and the frequency with which they appear to be "criminal."

Statistics on adultery and fornication convictions in nineteenth-century Hawai' $i$ provide one illustration of this process. During the 1820 s and I 830 , New England missionaries became powerful advisors to the Hawaiian $m o^{\prime} i$ (king) and pressed for laws governing family life and sexuality as well as preventing social disorder. After I 876, when the Reciprocity Treaty was signed giving Hawaiian sugar privileged access to the US market, the social order in Hawai'i was increasingly dominated by plantations, with their distinctive forms of discipline and order. Planters were constantly seeking new sources of low-cost labor for plantation work. The low pay, grim working and living conditions, and quasi-slave contract system drove each group out of the plantations as soon as possible, necessitating new labor sources. The importation of Chinese laborers began in 1852 , continued slowly until I 875 , then accelerated until I 886 . Portuguese sugar fieldworkers were imported between I 877 and I9I3, Japanese workers 
from I 884 until I906, Puerto Ricans from I900, and Filipinos from I906 to the I940s. By the end of the nineteenth century, a small number of white Americans and Europeans controlled a largely Hawaiian, Portuguese, and Asian labor force.

New laws criminalizing adultery and fornication were introduced into the sovereign Kingdom of Hawai'i in the I 830 s under the influence of American missionary advisors. These missionaries saw changing the nature of the family and constraining sexual freedom as fundamental to Christian conversion. Their notion of marriage as a permanent and sexually circumscribed relationship differed significantly from that of most segments of Hawaiian society at the time. As a result, from the I 830 os to the 1850 courts spent much of their time prosecuting adultery and fornication cases. In the lower court in the town of Hilo on the island of Hawai'i, for example, adultery, fornication, and prostitution accounted for almost half ( 44 percent) of the caseload in I 853 . Although these cases dropped over time, almost all the defendants were Native Hawaiians. As newcomer populations flooded into Hawai'i in the late nineteenth century, they were not prosecuted for adultery and fornication in significant numbers. The energetic police and judicial activity was directed not at rooting out and punishing every incident of adultery and fornication, but at transforming the family life of the Native Hawaiians, the primary objects of conversion and transformation. As the social reformist missionaries lost control of the judiciary in the late nineteenth century, the number of adultery and fornication cases in the Hilo court dropped precipitously, to 3 percent in 1903 (see table 3).

Clearly, Native Hawaiians were confronting a system of regulations that criminalized their family practices as well as a group of reform-oriented politicians who focused on Native Hawaiian family life. The reformers encouraged citizens to report their neighbors; some Hawaiians who were Christian converts complied. Reformist Christian judges were willing to prosecute and convict. The reformers used the court processes to solidify the new form of marriage among the Native Hawaiian population. But if one simply examined the court records without considering this social and political context of this offense and its energetic prosecution, it would appear that the Native Hawaiians were simply a more "criminal" population than the other groups living in the country at the same time.

A second example shows that the definition of a crime can also reflect particular economic relationships and demands for land and labor. Laws introduced to the Kingdom in 1848 and 1850 privatized landownership, 
allowed its purchase by foreigners, and created a labor relationship based on contractual agreements that were enforceable by criminal courts. These legal arrangements were imported from the United States and had no basis in Native Hawaiian law and practice. As the sugar plantation economy expanded in the years after I 876, these legal arrangements allowed plantation owners to employ imported laborers from Europe and Asia and impose fines or imprisonment for refusal to work. During the last quarter of the nineteenth century labor violation cases made up about a third of the total caseload in the Hilo courts ( 40 percent in 1873,38 percent in I 883, 22 percent in I 893). The ethnicity of the defendants changed over time as the ethnicity of the labor force itself shifted, each newcomer group appearing in disproportionate numbers. This intensive prosecution of labor violations created a "criminal" population caught up in a penal system of labor. Meanwhile, the sheriff, the judges, and the attorneys in Hilo all maintained close personal and economic relationships with the elites in the sugar plantation industry, and some owned plantations themselves. The courts were criminalizing the newcomer population in order to promote the economic growth of the plantation economy and to protect their own class interests.

These two examples demonstrate that the creation of a "criminal" population is a social process that depends on the way offenses are defined, public opinion is excited, and judicial attention is focused. But public and

Table 3. Annual Legal Violations by Category, Hilo District (Percent)

\begin{tabular}{lccccccc}
\hline Year & $\begin{array}{c}\text { Adultery or } \\
\text { Prostitution }\end{array}$ & $\begin{array}{c}\text { Work } \\
\text { Offenses }\end{array}$ & $\begin{array}{c}\text { Public } \\
\text { Order }\end{array}$ & $\begin{array}{c}\text { Drugs and } \\
\text { Alcohol }\end{array}$ & Gambling & Violence & Other \\
\hline 1853 & 44 & 4 & 10 & 9 & 2 & 19 & 12 \\
1863 & 28 & 23 & 9 & 4 & 0 & 12 & 24 \\
1873 & 6 & 40 & 2 & 16 & 4 & 10 & 22 \\
1883 & 2 & 38 & 4 & 14 & 0 & 11 & 31 \\
1893 & 1 & 22 & 5 & 19 & 9 & 11 & 33 \\
1903 & 3 & 0 & 21 & 18 & 9 & 13 & 36 \\
Overall & 8 & 24 & 9 & 16 & 5 & 12 & 26 \\
\hline
\end{tabular}

Source: Hilo District Court records. 
judiciary interest respond to social reform efforts and economic needs. For example, in the r99os an explosion of cases of wife battering in Hawai' $i$ courts may reflect increasing patterns of violence against women but also an increasing public awareness of women's rights and a readiness on the part of police, prosecutors, and judges to hear complaints (Merry 1995).

Thus, the disproportionate rates of arrest and conviction of Native Hawaiians follows from the fact that some actions are defined as crimes and are foregrounded as concerns by the public and criminal justice agencies and others are not. For example, a focus on the traffic in drugs by small sellers and users rather than on the organized crime figures who stand at the top of the drug business or on corporations that engage in illegal labor and environmental practices snares a disproportionate number of Native Hawaiians. To label one group criminal on the basis of patterns of differential attention and enforcement is clearly misleading and inaccurate.

\section{Criminalization in Hawai'i}

A historical perspective on the changing definitions of crime and the shifting attention paid to various forms of crime is essential to understanding the situated nature of patterns of arrest and incarceration. An analysis of the shifting caseloads in the Hilo District Court during the nineteenth century illustrates these processes (see Merry 2000). Court records provide a measure of the kinds of behavior that were subject to criminalization. The changing caseload of the lower criminal court in one town in Hawai'i over the period I 853 to 1903 indicates that the court frequently defined everyday practices as crimes, but that the behaviors that were subject to its intervention shifted greatly over time. In order to examine the changing patterns, I recorded and counted all the cases from the Hilo District Court for a full year at ten-year intervals from I 853 to $1903 .{ }^{3}$ Judges in the Hilo District Court, as in other "police courts," were required to preserve "in written detail the minutes and proceedings of their trials, transactions, and judgments" according to the Organic Acts of I 847 that established them. For each year, for all cases, I recorded the charge, plea, conviction, disposition, presence of an attorney, and gender and ethnicity of the defendant. I also collected the texts of all cases involving interpersonal relationships for each year I examined. For about half of the period from I 853 to I903, court records were recorded in Hawaiian; the rest were in English. These records were ably translated by Esther Mookini and recorded by Marilyn 
Brown and Erin Campbell Framke. I recorded 2,325 cases in the district court of Hilo from I 853, I863, I873, I883, I893, and 1903 .

The kinds of cases handled by the court shifted significantly over these sixty years, but the bulk of the cases always concerned the practices of everyday life. For all cases combined, the major categories of offense were violations of work obligations (24 percent), drug and alcohol violations ( 16 percent), forms of violence ( 12 percent), offenses against the public order ( 9 percent), adultery or prostitution ( 8 percent), and gambling ( 5 percent).

But the proportion of these cases changed dramatically over time (see table 3). Adultery and prostitution, for example, declined markedly as a focus of court concern from 45 percent of all cases in 1853 , to 3 percent in 1903 (and ever lower percentages in I 883 and I 893). Almost all defendants were Hawaiian until I 883 , but Hawaiians remained the majority through I 893 even as their proportion of the population dropped dramatically. The adultery cases were part of the efforts of the New England missionaries and their descendants to reshape the family life of the Native Hawaiians; there was no similar concern for the family lives of the imported Asian and European laborers. As the missionaries lost influence to the planters, the subject of court intervention shifted.

As the plantation economy grew, work violations became an increasingly significant part of the court caseload, particularly the imposition of penal sanctions for failure to work. Work offenses constituted only 4 percent of the cases in 1853 , and 23 percent in 1863 . With the expansion of plantations in the late nineteenth century a larger proportion of court activity concerned work violations: 40 percent in 1873,38 percent by I 883,22 percent by 1893 , but none in 1903 - after the abolition of the contract labor system following annexation. (However, from I 893 to I903 public order offenses jumped from 5 percent to $2 \mathrm{I}$ percent of the caseload as vagrancy violations took the place of labor contract violations.) The ethnicity of the defendants shifted as the labor force changed, with Hawaiians being 97 percent of work violations defendants in I863, 94 percent in I873, and only 36 percent in 1883 when the proportion of Chinese defendants was 46 percent. In I 893, I0o percent of the defendants were Japanese.

Two other areas of everyday life appeared in district court over this time period. Drug and alcohol violations increased from a trickle in the early years to a major concern by the end of the century, increasingly targeting Chinese immigrants until they became fully integrated into the commercial and retail structure of the town. Sixteen percent of all charges over 
the $1853^{-1903}$ period were for drug and alcohol violations, but these accounted for only 9 percent of the caseload in 1853 and 4 percent in 1863 . By I873, I6 percent of the cases concerned drug and alcohol violations, and the percentage of the caseload on these charges varied between I 4 and I9 percent for the next three decades. Although more than half the defendants in 1873 were Hawaiian ( 54 percent), newcomers were disproportionately represented: nearly one-third were Chinese (3I percent) and about one-seventh were white ( 15 percent). In I 883, defendants in alcohol or drug cases were Chinese ( 35 percent), Hawaiian ( 28 percent), white ( 26 percent), and Portuguese (I I percent). In I893 drug and alcohol defendants were even more predominantly Chinese ( 45 percent) as well as Japanese ( 26 percent), and fewer were Hawaiian (2 I percent), white (4 percent), or Portuguese ( 3 percent). By I903, these offenses still represented I 8 percent of the caseload, but the Chinese had disappeared as defendants (only 2 percent), while most defendants were from the numerically dominant population, the Hawaiians ( 36 percent), and the newer immigrants, Japanese ( 24 percent), white ( 16 percent), Portuguese ( 9 percent), and Puerto Rican (9 percent). ${ }^{4}$

Gambling is another offense that was part of the everyday practices of many immigrants but was increasingly criminalized. Only 5 percent of all charges over the entire periodconcerned gambling, and there were no cases in $I 863$ and $I 883$, but these offenses grew from 2 percent in 1853 to 9 percent of the caseload in 1893 . Eighty-five percent of defendants in 1893 were Japanese. By I903, only 50 percent of defendants were Japanese, with another 34 percent Chinese, 9 percent Portuguese, and 3 percent Puerto Rican. Case records show that the offense of gambling occupied a much greater proportion of the court's work at the end of the nineteenth century than it had in mid-century, and prosecution tended to focus on the most recent immigrants. Violence, on the other hand, remained a steady proportion of the caseload between I 863 and I903, after dropping from a high of 19 percent in 1853 .

Thus, much of the work of the district court of Hilo concerned infractions that were part of everyday social life. Legal intervention concerned sexuality, drinking, festive activities such as cockfighting and gambling, and violations of work obligations. Court attention clearly shifted over time from a preoccupation with sexuality to drinking/drugs, gambling, and violations of the contract labor law. The focus of legal surveillance for these everyday offenses shifted from the Native Hawaiians in the I 850 and 1860 s to the immigrant plantation workers in the late nineteenth cen- 
tury, with a steady proportion of whites in the defendant population as well. In the early years of the court system, the New England missionaries used it to reshape the family and sexual lives of the Native Hawaiian population. With each wave of imported Asian and European laborers, similar efforts were directed to converting these primarily peasant farmers into a disciplined and reliable labor force for the plantations.

The criminalization of sexuality preceded the significant involvement of Hawaiians in wage labor on the sugar plantations. This disparity suggests that the fear of disorder and lack of self-restraint in sexual matters had its own impetus, not entirely derived from labor demands. Nineteenth and early twentieth century discussions of Hawaiians bemoaned their indolence and immorality, recommending regular labor as the solution, paralleling colonial discourses in plantations around the world. Work emerged as the center of discipline and self-discipline, to be achieved, ironically, through the power of the law.

\section{Conclusions}

Legislative and judicial processes determine which laws are passed and how crimes are defined. Under conditions of rapid change such as the imposition of colonial rule, these newly constituted "crimes" result in arrests, prosecutions, and convictions. But if criminal justice and judicial personnel are unwilling to arrest, to prosecute, and to convict, the laws make relatively little difference. A judge must accept the evidence, interpret the behavior as an example of the interdicted behavior, and impose a sentence. Crimes must also become part of popular consciousness about the nature of legal and illegal behavior. Particularly when everyday social practices are being redefined as crimes, the process of transforming popular consciousness and legitimating the new laws is uncertain and far from guaranteed. Enforcement of laws about new crimes requires some portion of the citizenry to be willing to report "criminal" behavior and provide evidence. Regulations about Hawaiian adultery, for example, had an effect only because roving constables were willing to report "adulterers" and to bring such persons to trial. Resistance by the regulated population is likely to cripple new laws. Individuals or groups can refuse the criminalization of normal behavior, sometimes by contesting the legitimacy of the legal system itself. Patterns of criminality are the product of all these social processes rather than simply variations in the frequencies of particular forms of conduct labeled criminal. 
It is likely that some of these processes contribute to the differential patterns of arrest and incarceration for ethnic groups in Hawai'i today. Decisions about which behaviors should be defined as crimes and warrant arrest, prosecution, and punishment are political and social decisions, inevitably shaped by what offenses are perceived as problems in a society. Only since the I980s has wife battering, for example, come to be understood as a serious crime warranting legal intervention, although attacking a woman had long been defined as the crime of assault. A history of colonization adds an important dimension to this process, because legal systems designed to establish control over a colonized population may retain features of that orientation. The process of criminalization is guided by preexisting understandings of racial as well as class and gender identities, but as members of these groups are differentially arrested, prosecuted, and convicted, these identities are generated and reinforced. Thus, understanding differential crime rates as a consequence of the social process of criminalization rather than as an indication of a group's inherent criminal tendencies is important in refiguring the present as well as the past.

* * *

THE RESEARCH FOR THIS PROJECT was generously supported by the National Science Foundation, the National Endowment for the Humanities, and the Canadian Institute for Advanced Research.

\section{Notes}

I The US Census 2000 made an effort to deal with multiple racial identifications, which in Hawai'i produced a large proportion of multiply raced people. Only 78.6 percent identified themselves as having a single race, while 2 I. 4 percent described themselves according to two or more races. As a result, there are more racial responses than persons, with the racial responses adding up to I 29.4 percent of the total population. The same person can be counted in two or three racial categories. The disparity between 9.4 percent who say they are Native Hawaiian or Pacific Islander alone and the 23.3 percent who say they are a combination of some other race and Native Hawaiian or Pacific Islander reflects the high proportion of Native Hawaiians with multiple identifications. Table I points up similar disparities for the Asian and white categories. In contrast, the arrest statistics do not consider the impact of people with multiple identities. This makes these comparisons somewhat ambiguous. The new census format reflects more accurately the nature of identity in Hawai' $i$ than the arrest statistics, but its results are clearly unwieldy for statistical analysis. 
2 These patterns existed in the early I990s as well. In I993, 22.7 percent of those arrested for Type I offenses and 20.2 percent of those arrested for Type II offenses were Hawaiians, who represented just I 2.5 percent of the state's population (Hawai'i State Attorney General I993, I04). (Type I offenses include murder, forcible rape, robbery, aggravated assault, burglary, larceny-theft, and motor vehicle theft; Type II offenses are less serious crimes such as manslaughter, assault, vandalism, prostitution, driving under the influence of drugs or alcohol, and the possession, sale, or manufacture of drugs.)

3 These records are housed in the Hawai'i State Archives in Honolulu. The minute books have been preserved in a virtually complete set from Hilo from the I850s until I9I0, but subsequent records were destroyed.

4 The diminished proportion of Chinese defendants in alcohol or drug cases in 1903 is partly explained by a drop in the percentage of Chinese in the overall defendant population from I 893 (I 8 percent) to 1903 (9 percent).

\section{References}

\section{Hawaici State Attorney General}

I993 Crime in Hawai i. Honolulu: Department of the Attorney General, Crime Prevention Division, State of Hawai'i.

Hawai'i State Department of Corrections

1990 Statistical Report of Hawai'i's Jail Population, Admissions, and Releases, 1983/84-1987/88. Honolulu: Department of Corrections, Administrative Services Division, Correctional Information and Statistics Office, Research and Records Section, State of Hawai'i.

Merry, Sally Engle

I995 Gender Violence and Legally Engendered Selves. Identities: Global Studies in Culture and Power 2:49-73.

2000 Colonizing Hawai' $i$ : The Cultural Power of Law. Princeton, NJ: Princeton University Press.

Richmond, James B, and Paul A Perrone

I997 Data Brief: Drug Offense Arrests in Hawai'i, 1982-1996. Honolulu: Department of the Attorney General, Crime Prevention and Justice Assistance Division, State of Hawai'i.

Richmond, James, Joe Allen, and Paul A Perrone

2000 Crime in Hawai'i I 999: A Review of Uniform Crime Reports. Honolulu: Department of the Attorney General, Crime Prevention and Justice Assistance Division, Research and Statistics Branch, State of Hawaici. <www.cpja.ag.state.hi.us>

United States Census

$2000<$ www.census.gov> 


\section{Abstract}

Native Hawaiians are disproportionately arrested and incarcerated in the state of Hawai $i$, according to statistics from the criminal justice system. Asians are underrepresented and whites are represented slightly above their proportion of the population. Although these statistics have sometimes been used to make arguments about criminal propensities, this article argues that such differences are not inherent but are socially produced. They reflect the kinds of behavior that are defined as criminal and subjected to energetic arrest, prosecution, and conviction while other behaviors are ignored. Using historical data, this article argues that criminalization is a social process that zeroes in on certain populations and their activities and that its targets change with alterations in historical circumstances.

KEYWORDS: Hawai'i, crime, colonialism, historical anthropology, criminalization, law 